\title{
Selenium supplementation into diets containing carnosic acid, fish and rapeseed oils affects the chemical profile of whole blood in lambs
}

\author{
M. Czauderna ${ }^{1,3}$, M. Białek¹, K.A. Krajewska1', A. Ruszczyńska² and E. Bulska² \\ ${ }^{1}$ The Kielanowski Institute of Animal Physiology and Nutrition, Polish Academy of Sciences \\ Instytucka 3, 05-110 Jabłonna, Poland \\ ${ }^{2}$ University of Warsaw, Faculty of Chemistry, Biological and Chemical Research Centre \\ Żwirki i Wigury 101, 02-089 Warsaw, Poland
}

KEY WORDS: selenium, fish oil, carnosic acid, blood, fatty acids, elements, lambs

Received: $\quad 2$ March 2017

Revised: $\quad 5$ June 2017

Accepted: 8 September 2017

${ }^{3}$ Corresponding author:

e-mail: m.czauderna@ifzz.pl

\begin{abstract}
The concentration of macro and trace elements, fatty acids (FAs), vitamins, total cholesterol (TCh) in blood as well as in other tissues can be modulated by diet composition. Thus, the purpose of the present study was to evaluate the effects of fish oil (FO), carnosic acid (CA) and selenized-yeast (SeY) or selenate (SeVI) on concentration of FAs, TCh, a-tocopherol (aT) and selected elements in whole blood of lambs. Thirty male lambs were allocated into 5 groups of 6 animals each and fed for 35 days the following diets: control - basal diet (BD) with $3 \%$ rapeseed oil (RO), ROFO - BD with $2 \%$ RO and $1 \% \mathrm{FO}, \mathrm{CA}-\mathrm{BD}$ with $2 \% \mathrm{RO}, 1 \% \mathrm{FO}$ and $0.1 \% \mathrm{CA}, \mathrm{CASeY}-\mathrm{BD}$ with $2 \%$ $\mathrm{RO}, 1 \% \mathrm{FO}, 0.1 \% \mathrm{CA}$ and $0.35 \mathrm{mg}$ Se as selenized-yeast (SeY) per $\mathrm{kg}$ of $\mathrm{BD}$ and CASeVI - BD with $2 \%$ RO, $1 \% \mathrm{FO}, 0.1 \% \mathrm{CA}$ and $0.35 \mathrm{mg}$ Se as sodium selenate (SeVI) per kg of BD. In animals fed CASeVI diet the levels of saturated (SFAs), mono- and polyunsaturated FAs, thrombogenic-SFAs and atherogenicSFAs decreased in comparison to the control group. On the other hand, in lambs fed CASeY diet the concentration of TCh in blood increased in comparison to lambs fed CA and CASeVI diets. Moreover, feeding CASeY diet also enhanced the concentration of aT in blood as compared to the animals fed ROFO and CASeVI diets. The lowest aT concentration in blood was noted in blood of lambs fed CASeVI diet. Feeding diets supplemented with SeY or SeVI increased the concentrations of Se and malondialdehyde in blood in comparison to other diets. So, the whole blood can be treated as the valuable non-invasive marker for evaluation of ruminant health status and nutritional quality of ruminant feeds.
\end{abstract}

\section{Introduction}

Whole blood consists of plasma $(\sim 54 \%)$ and various types of circulating cells $(\sim 46 \%)$ with a very low percentage of cells other than erythrocytes (Jones and Allison, 2007). The main ester-lipid components of blood are triacylglycerols, cholesterol esters and glycerophospholipids. The concentrations of essential elements (like $\mathrm{Se}, \mathrm{Zn}, \mathrm{Cu}, \mathrm{Co}, \mathrm{Fe}$ or $\mathrm{Mg}$ ), fatty acids (FAs), vitamins or cholesterol in plasma and circulating blood cells as well as in other mammal tissues vary due to different physiological factors (i.e. dietary intake, intestinal absorption, metabolism and exchange among compartments) (Kincaid, 1999; Risé et al., 2007; Juniper et al., 2008; Niedźwiedzka et al., 2008; Czauderna et al., 2010). 
According to the previous studies, the most abundant FAs in plasma and whole blood are C16:0, C18:0, cis9C18:1 (c9C18:1), $\quad c 9 c 12 \mathrm{C} 18: 2 \quad$ (LA) and $c 5 c 8 c 11 c 14 \mathrm{C} 20: 4$ (AA) with minor concentrations of long-chain polyunsaturated fatty acids (LPUFAs) (Risé et al., 2007; Niedźwiedzka et al., 2008; Czauderna et al., 2010). Although, the FAs profile is usually typical for each lipid class, it also reflects the fatty acid concentration of diets (Skeaff et al., 2006; Czauderna et al., 2010; Rozbicka-Wieczorek et al., 2016a,b,c). So, fish oil (FO) added to diet increases the content of LPUFAs (especially prohealth n-3LPUFAs) in ruminant tissues. Fortunately, LPUFAs derived from FO are also known to inhibit the complete ruminal biohydrogenation of C18-unsaturated FAs to stearic acid resulting in an accumulation of trans 11C18:1 (t11C18:1) - the precursor of $c 9, t 11 \mathrm{C} 18: 2$ (Wąsowska et al., 2006).

Moreover, our recent studies indicated that carnosic acid (CA; the phenolic compound) and/or Secompounds added to the diet influenced the concentrations of FAs, cholesterol and essential elements (like Se or Zn) in lamb muscles (Miltko et al., 2016; Rozbicka-Wieczorek et al., 2016a,b,c; Ruszczyńska et al., 2016).

Cholesterol can exist in the organism in a free form or it can be esterified to a fatty acid as cholesteryl ester. In blood the two thirds of cholesterol is in the esterified form and transferred through bloodstream in small compounds called lipoproteins containing outer shell (built by phospholipid, cholesterol and apolipoproteins) and core containing lipids molecules (Orth and Bellosta, 2012). Ruminants utilize cholesterol for the biosynthesis of hormones, vitamin D and substances that contribute in nutrients digestion. Cholesterol is produced by the organism itself but it can be also administrated with several foods. Unfortunately, the high level of saturated fatty acids and cholesterol in diet increases blood cholesterol levels. The high blood cholesterol level is one of the major risk factors for cardiovascular diseases. Moreover, the previous studies documented that diet rich in such essential mineral as Se also increases total cholesterol level in blood as well as contribute to $10 \%$ increase in non-HDL cholesterol concentration in plasma (University of Warwick, 2009).

It was recently shown that diet enriched with Se-compounds and CA (both with antioxidative properties) modifies ruminal microbiota and hence FAs metabolism in the rumen (Morán et al., 2013; Birtić et al., 2015). As a consequence, the addition of dietary Se-compounds and/or CA affects FAs profile and levels of amino acids in the rumen and has a significant influence on biosynthesis of volatile compounds and concentrations of FAs, cholesterol and amino acids in lamb tissues (Miltko et al., 2016; Rozbicka-Wieczorek et al., 2016a,b,c). Moreover, the main physiological role of Se-cysteine containing proteins is the maintenance of low concentrations of free radicals (like reactive oxygen species) within cells that are closely linked to oxidative stress and peroxidative damage of PUFAs and cholesterol in tissues.

Considering the above, we hypothesized that dietary FO (rich in n-3LPUFAs) would influence concentration of essential elements (especially Se and $\mathrm{Zn}$ ) and increase concentrations of LPUFAs as well as products of PUFA peroxidation in whole blood of lambs. Moreover, we assumed that CA, selenizedyeast $(\mathrm{SeY})$ or selenate $(\mathrm{SeVI})$ added to the diet with FO would reduce the concentrations of malondialdehyde (MDA; the non-invasive marker of PUFA peroxidation), total cholesterol (TCh) and tocopherols in blood.

Thus, the goal of our study was to investigate the possible effects of FO without or with the antioxidants such as CA, SeY or SeVI added to diets with rapeseed oil (RO) on concentrations of FAs, TCh, $\alpha$-tocopherol $(\alpha \mathrm{T})$ and especially MDA in lamb whole blood.

\section{Material and methods}

\section{Animals and experimental design}

Thirty Corriedale male lambs with similar body weight $(24.3 \pm 1.6 \mathrm{~kg})$ and age (82-90 days) were randomly selected from a large herd ( $\sim 110$ male lambs). Animals were divided into five groups of six lambs and individually penned. The study was conducted under the authority of the Third Local Commission of Animal Experiment Ethics at the Warsaw University of Life Sciences (Warsaw, Poland).

During a 3-week preliminary period the animals had ad libitum access to fresh drinking water and basal diet (the standard concentrate-hay diet with mineral and vitamin premix) enriched in $3 \% \mathrm{RO}$ or $2 \% \mathrm{RO}$ and $1 \%$ FO (Table 1 ). The quantity of the basal diet with oil(s) was weekly adjusted to lamb requirements. The basal diet (meadow hay $(\sim 36 \%)$, mixture of soyabean meal $(\sim 36 \%)$, barley meal $(\sim 16.5 \%)$, wheat starch $(\sim 9 \%)$, mineral-vitamin premix $\left(20 \mathrm{~g} \cdot \mathrm{kg}^{-1} \mathrm{BD}\right)$ and oil(s)) (Tables 1 and 2) was offered in two equal meals at 7:30 and 16:00 each day.

Chemical composition of diets was analysed according to AOAC International (2005). 
Table 1. Chemical composition of ingredients (concentrate-hay diet with vitamin and mineral mixture ${ }^{1}$ ) in basal diet and chemical composition of control and experimental diets (means, $n=3$ )

\begin{tabular}{|c|c|c|c|c|}
\hline \multicolumn{5}{|c|}{ Chemical composition of basal diet (BD)² ingredients, \% in dry matter (DM) } \\
\hline \multirow{2}{*}{ Indices } & \multirow{2}{*}{$\begin{array}{l}\text { Meadow } \\
\text { hay }^{3}\end{array}$} & \multicolumn{3}{|l|}{ Concentrate $^{3}$} \\
\hline & & barley meal & soyabean meal & wheat starch \\
\hline Dry matter, \% BD & 88.4 & 87.6 & 89.7 & 87.3 \\
\hline Crude protein & 9.50 & 9.94 & 41.81 & 0.90 \\
\hline Crude fibre & 27.29 & 2.87 & 4.34 & - \\
\hline Crude fat & 3.40 & 2.50 & 2.25 & 0.09 \\
\hline Ash & 4.85 & 1.84 & 6.16 & 0.12 \\
\hline Neutral detergent fibre & 59.17 & 18.02 & 18.81 & - \\
\hline Acid detergent fibre & 32.08 & 4.61 & 6.44 & - \\
\hline Acid detergent lignin & 4.47 & 1.14 & 1.49 & - \\
\hline
\end{tabular}

Chemical composition of control ${ }^{4}$ and experimental diets $^{5}$

\begin{tabular}{|c|c|}
\hline Dry matter, $\mathrm{g} \cdot \mathrm{kg}^{-1} \mathrm{BD}$ & 884.3 \\
\hline Crude protein, $\mathrm{g} \cdot \mathrm{kg}^{-1} \mathrm{DM}$ & 201.9 \\
\hline Crude fibre, $\mathrm{g} \cdot \mathrm{kg}^{-1} \mathrm{DM}$ & 118.6 \\
\hline Crude fat ${ }^{6}, \mathrm{~g} \cdot \mathrm{kg}^{-1} \mathrm{BD}$ & 21.7 \\
\hline Total crude fat ${ }^{7}, \mathrm{~g} \cdot \mathrm{kg}^{-1} \mathrm{BD}$ & 51.7 \\
\hline Ash, $\mathrm{g} \cdot \mathrm{kg}^{-1} \mathrm{DM}$ & 42.8 \\
\hline Neutral detergent fibre, $\mathrm{g} \cdot \mathrm{kg}^{-1} \mathrm{DM}$ & 310.5 \\
\hline Acid detergent fibre, $\mathrm{g} \cdot \mathrm{kg}^{-1} \mathrm{DM}$ & 146.3 \\
\hline Acid detergent lignin, $\mathrm{g} \cdot \mathrm{kg}^{-1} \mathrm{DM}$ & 23.3 \\
\hline Gross energy of $\mathrm{BD}, \mathrm{MJ} \cdot \mathrm{kg}^{-1} \mathrm{DM}^{8}$ & 16.760 \\
\hline Gross energy of control diet, $\mathrm{MJ} \cdot \mathrm{kg}^{-1} \mathrm{DM}$ & 17.870 \\
\hline experimental diets, $\mathrm{MJ} \cdot \mathrm{kg}^{-1} \mathrm{DM}$ & 17.868 \\
\hline
\end{tabular}

$11 \mathrm{~kg}$ of mineral and vitamin mixture comprised: $\mathrm{g}$ : Ca 285, P 16, Na 56, Fe as sulphate 1, Cu as sulphate $0.5, \mathrm{Mn}$ as sulphate $5.8, \mathrm{Zn}$ as sulphate 7.5; mg: Co as carbonate 42, iodine as iodate 10, Se as selenite 6; IU: vit. A 500 000, vit. D 125 000, a-tocopherol $25000 ; 20 \mathrm{~g}$ of mineral and vitamin mixture was added to $1 \mathrm{~kg}$ of $\mathrm{BD} ;{ }^{2}$ gross energy, $\mathrm{MJ} \cdot \mathrm{kg}^{-1}$ of DM: meadow hay 17.1 , barley meal 16.3 , soyabean meal 17.8 , wheat starch 16.7; ${ }^{3}$ fatty acids (FAs) concentration $\left(\mathrm{mg} \cdot \mathrm{kg}^{-1}\right.$ ) in: concentrate: C14:0 104, C16:0 3189, C18:0 1425, c9C18:1 1774, c9c12C18:2 (LA) 29163 and c9c12c15C18:3 (aLNA) 1014; meadow hay: C8:0 83, C12:0 142, C14:0 239, c9C15:1 131, C16:0 4034, c9C16:1 184, C18:0 459, c9C18:1 1266, c12C18:1 72, LA 13 100, aLNA 4178, C20:0 58, c11C20:1 74, C22:0 101, C24:0 69 and c15C24:1 71; FAs in concentrate and meadow hay were analysed by Rozbicka-Wieczorek et al. (2016b); ${ }^{4} \mathrm{BD}$ supplemented with $3 \%$ rapeseed oil (RO); ${ }^{5} \mathrm{BD}$ supplemented with $2 \%$ RO, $1 \%$ odourless fish oil (FO) without or with antioxidant(s) (i.e. carnosic acid (CA), selenized-yeast (SeY) or selenate (SeVI)) (see Table 2); ${ }^{6}$ crude fat originating from BD (i.e. meadow hay and concentrate); ${ }^{7}$ total crude fat originating from BD and supplemented oil(s) (i.e. RO without or with FO); ${ }^{8}$ gross energy of $\mathrm{BD}$ (i.e. meadow hay and concentrate) without supplementation with RO, FO, CA and Se (SeY or SeVI)

After the preliminary period, the 35-day dietary experiment was conducted, during which lambs were fed the basal diet (BD) enriched with 3\% RO (control diet; group I), with $2 \% \mathrm{RO}$ and $1 \% \mathrm{FO}$ (group II) or with $2 \% \mathrm{RO}, 1 \% \mathrm{FO}$ and antioxidants $(0.1 \% \mathrm{CA}$ or/and $0.35 \mathrm{ppm}$ Se as selenized-yeast or selenate) (groups III-V) (Table 2).

The energy content of RO and odourless FO was 37.0 and $36.8 \mathrm{MJ} \cdot \mathrm{kg}^{-1}$ oil, respectively. As a consequence, the control and all experimental diets were formulated to be isonitrogenous and isoenergetic (Table 1). Diets were offered in two equal meals at 7:30 and 16:00 each day. The quantity of the control and experimental diets was weekly adjusted to lamb requirements according to Strzetelski et al. (2014). There were no feed refusals (Table 2). The average daily feed intake was $1.08 \mathrm{~kg}$ per animal. Lambs had also free access to fresh drinking water. After the 35-day experiment (i.e. at 7:00 after $12 \mathrm{~h}$ of starving), blood samples from the jugular vein were collected into heparinized tubes. Collected blood samples were stored at $-32{ }^{\circ} \mathrm{C}$ till further analysis; each blood sample was analysed separately.

\section{Reagents}

Acetonitrile, n-hexane and methanol were purchased from Lab-Scan (Dublin, Ireland). Other HPLC and GC reagents were of analytical grade (Avantor Performance Materials Poland S.A, Gliwice, Poland). Fatty acid standards, conjugated linoleic acid (CLA) mixture, $25 \% \mathrm{BF}_{3}$ in methanol, sodium selenate (SeVI), 5-cholestane (the internal standard), 2,4-dinitrophenyl-hydrazine, 2,6-di-tert-butyl-p-cresol and 1,1,3,3-tetramethoxy propane were provided by Sigma-Aldrich (St. Louis, MO, USA). Tocopherol standards, cholesterol, dichloromethane, $\mathrm{KOH}, \mathrm{NaOH}$ and 
Table 2. Group characterisation with composition of control diet (containing rapeseed oil $\left.(\mathrm{RO})^{1}\right)$ and experimental diets containing additionally odourless fish oil (FO) ${ }^{2}$ without or with antioxidants (i.e. carnosic acid (CA), selenized-yeast (SeY) or selenite (SeVI)), and body weight (BW) and feed conversion efficiency (FCE) of lambs

\begin{tabular}{|c|c|c|c|c|}
\hline \multirow{2}{*}{ Groups } & \multirow{2}{*}{ Additives added to basal diet (BD) } & \multicolumn{2}{|l|}{$\mathrm{BW}, \mathrm{kg}$} & \multirow{2}{*}{$\begin{array}{l}\text { FCE, } \\
\mathrm{kg} \mathrm{BW} \text { gain } \cdot \mathrm{kg}^{-1} \text { diet intake }\end{array}$} \\
\hline & & $\mathrm{BW}_{\text {initial }}{ }^{3}$ & $\mathrm{BW}_{\text {final }}{ }^{4}$ & \\
\hline Group I5 (control) & $\begin{array}{l}3 \% \mathrm{RO} \\
\text { (control } \operatorname{diet}^{7} \text { ) }\end{array}$ & $30.7 \pm 2.5$ & $36.3 \pm 2.8^{a}$ & $0.150 \pm 0.001^{\mathrm{a} \alpha}$ \\
\hline Group $\|^{6}$ & $\begin{array}{l}2 \% \text { RO and } 1 \% \text { FO } \\
\left(\text { ROFO } \text { diet }^{7}\right)\end{array}$ & $30.6 \pm 2.1$ & $37.7 \pm 1.8^{\mathrm{ab}}$ & $0.189 \pm 0.001^{\mathrm{ab} \beta}$ \\
\hline Group III & $\begin{array}{l}2 \% \mathrm{RO}, 1 \% \mathrm{FO} \text { and } 0.1 \% \mathrm{CA} \\
\left(\mathrm{CA} \operatorname{diet}^{7}\right)\end{array}$ & $30.6 \pm 1.9$ & $37.2 \pm 1.4^{a}$ & $0.174 \pm 0.001^{\mathrm{a}}$ \\
\hline Group IV6 & $\begin{array}{l}2 \% \mathrm{RO}, 1 \% \mathrm{FO}, 0.1 \% \mathrm{CA} \text { and } 0.35 \mathrm{ppm} \text { Se as } \mathrm{SeY} \\
\left(\mathrm{CASeY} \text { diet }^{7}\right)\end{array}$ & $30.3 \pm 1.3$ & $36.8 \pm 1.4^{a}$ & $0.174 \pm 0.001^{\mathrm{a}}$ \\
\hline Group V 6 & $\begin{array}{l}2 \% \mathrm{RO}, 1 \% \mathrm{FO}, 0.1 \% \mathrm{CA} \text { and } 0.35 \mathrm{ppm} \text { Se as SeVI } \\
\left(\mathrm{CASeVI} \operatorname{diet}^{7}\right)\end{array}$ & $30.3 \pm 2.1$ & $38.5 \pm 2.7^{b}$ & $0.215 \pm 0.001^{\mathrm{b}}$ \\
\hline
\end{tabular}

${ }^{1} \mathrm{RO}$ contained following fatty acids (FAs), $\mathrm{mg} \cdot \mathrm{kg}^{-1}: \mathrm{C} 14: 056, \mathrm{C16}: 0$ 13091, c9C16:1 33, C18:0 5490, c9C18:1 385859, c12C18:1 786, LA282394, aLNA38474, C20:0 194, c11C20:1 108, C22:0 430 and c15C24:1 61 (analysed by Rozbicka-Wieczorek et al., 2016b); ${ }^{2}$ FO contained following FAs, $\mathrm{mg} \cdot \mathrm{kg}^{-1}$ : C12:0 82, C14:0 12345, c9C14:1 215, C15:0 477, C16:0 56947, c7C16:1 318, c9C16:1 420, ¿C16:2 15586, C17:0 493, c9C17:1 193, C18:0 9452, c6C18:1 188, c7C18:1 842, c9C18:1 290592, c12C18:1 15834, c14C18:1 159, LA 114512, aLNA 20968, c11C20:1 24206, c7c9c12c15C18:4 473, c11c14C20:2 2270, c8c11c14C20:3 258, c5c8c11c14C20:4 304, c8c11c14c17C20:4 607, C22:0 139, c13C22:1 11036, c11C22:1 1704, c5c8c11c14c17C20:5 (EPA) 6792, c13c16C22:2 95, c7c10c13c16C22:4 144, c15C24:1 397, c7c10c13c16c19C22:5 (DPA) 1560 and c7c10c13c16c19C22:6 (DHA) 26570 (analysed by Rozbicka-Wieczorek et al., 2016b); ${ }^{3}$ average initial body weight (kg) of lambs after 3-week preliminary period; ${ }^{4}$ average body weight $(\mathrm{kg})$ of lambs fed diets in 35 -day experimental period; ${ }^{5}$ in 3-week preliminary period lambs were fed $\mathrm{BD}$ with $3 \% \mathrm{RO} ;{ }^{6}$ in 3-week preliminary period lambs were fed $\mathrm{BD}$ with $2 \% \mathrm{RO}$ and $1 \% \mathrm{FO} ;{ }^{7}$ concentration of Se in control, ROFO and CA diets was $0.16 \mathrm{ppm}$; concentration of Se in CASeY and CASeVI diets was $0.51 \mathrm{ppm}$ (Ruszczyńska et al., 2016); BW and FCE data are presented as means and the corresponding root-mean-square error (RMSE) of the means; ab - means with different superscripts within the same column are significantly different at $P \leq 0.05$; ${ }^{\alpha, \beta}$ - means with different superscripts within the same column tend to be different at $0.05<P \leq 0.10$

concentrated $\mathrm{HCl}$ were obtained from Avantor Performance Materials Poland S.A. (Gliwice, Poland). The organic solvents were of HPLC grade. Carnosic acid (CA) was purchased from Hunan Geneham Biomedical Technology Ltd. (Changsha, Hunan, China). RO and odourless FO were supplied by Company AGSOL (Pacanów, Poland). The vitamin and mineral mixture Polfamix O-K was purchased from Trouw Nutrition (Grodzisk Mazowiecki, Poland). The selenized-yeast (Se-Saccharomyces cerevisiae; $\mathrm{SeY}$ ) was in the form of Sel-Plex (Alltech Inc., St. Louis, MO, USA). In general, approximately $83 \%$ of the total Se-content of the $\mathrm{SeY}$ is in the form of Se-methionine (Se-Met) and 5\% is in the form of Se-cysteine (Se-Cys) incorporated into the proteins of Saccharomyces cerevisiae (Czauderna et al., 2009a).

\section{Analytical methods and chromatographic equipment}

Whole blood samples (15-20 mg) were saponified using $\mathrm{KOH}$ solution according to methods described by Rozbicka-Wieczorek et al. (2014). Then, base- and acid-catalysed methylations were introduced for the preparation of FAs methyl esters in processed biological samples (Rozbicka-Wieczorek et al., 2014). Methylated fatty acids (FAME) in whole blood samples were then quantified using cap- illary gas chromatography with mass spectrometry (GC-MS) according to methods presented by Rozbicka-Wieczorek et al. (2014). The FAME analyses were performed on a Shimadzu GC-MS-QP2010 Plus EI equipped with a BPX70 fused silica column (120 m (length) $\times 0.25 \mathrm{~mm}$ (i.d.) $\times 0.25 \mu \mathrm{m}$ (film thickness)), a quadruple mass selective detector (Model 5973N) and an injection port (Phenomenex, Torrance, CA, USA). FAME identification was validated based on electron impact ionization spectra of FAME and compared to authentic FAME standards and the NIST 2007 reference mass spectra library (National Institute of Standard and Technology, Gaithersburg, MD, USA). All FAME analyses performed on blood samples were based on total ion current chromatograms and/or selectedion monitoring chromatograms.

TCh and $\alpha \mathrm{T}$ were quantified in whole blood samples using an ultra-fast liquid chromatography system (Shimadzu, Tokyo, Japan) according to methods of Czauderna et al. (2009b). The MDA concentration in blood samples was determined after saponification followed by derivatization according to Czauderna et al. (2011). The quantification of derivatized MDA in blood samples was conducted using an ultra-fast liquid chromatography system (Shimadzu, Kyoto, Japan). This chromatographic 
instrument consisted of an ultra-fast liquid chromatography system (UFLC-DAD), incorporating two LC-20ADXP pumps (UFLCXR), a SIL-20ACXR autosampler (LFLCXR), a CBM-20A communications bus module, a CTO-20A column oven, a DGU-20A5 degasser and a SPD-photodiode array detector.

The concentrations of $\mathrm{Se}, \mathrm{Zn}, \mathrm{Cu}, \mathrm{Mg}, \mathrm{Ca}, \mathrm{Fe}$, $\mathrm{As}, \mathrm{Cd}$ and $\mathrm{Pb}$ in whole blood sample were determined according to Kurek et al. (2009). Closedvessel microwave-assisted unit (Anton Paar Mutliwave Sample Preparation System, Graz, Austria) with teflon vessels was used for samples mineralization. The elemental compositions of Se in diets and whole blood samples were then quantified using a mass spectrometer (Perkin Elmer Sciex, Dallas, TX, USA).

\section{Statistical analyses}

The obtained results are presented as mean values with standard error of means (SEM). The significance of difference between means of different groups were estimated by using the Tukey test. Polynomial contrasts were also used to determine linear effects of the diets enriched with FO, $\mathrm{CA}$ and/or $\mathrm{Se}$ (as $\mathrm{SeY}$ or $\mathrm{SeVI}$ ) on the contents of fatty acids, TCh, $\alpha \mathrm{T}, \mathrm{MDA}$ and selected elements in whole blood samples. Statistical analyses were performed using the STATISTICA ver. 10 PL software package (StatSoft Inc., Tulsa, OK, USA).

\section{Results}

No adverse symptoms (like vomiting or diarrhoea) in lambs fed diets containing FO, CA, SeY or SeVI were observed. Feeding lambs with the CASeVI diet (group V) increased $(P \leq 0.05)$ body weight (BW) and worsened feed conversion efficiency (FCE) when compared to lambs fed the control (group I), CA (group III) and CASeY (group IV) diets (Table 2).

When the lambs were fed CASeVI diet (group $\mathrm{V})$ decreased concentrations of sum of saturated fatty acids (LSFA) (including C10:0, C16:0, C17:0 and $\mathrm{C} 18: 0)$, the thrombogenic SFA (T-SFA) and the atherogenic SFA (A-SFA) were noted in comparison to animals fed the control diet $(P \leq 0.05$; Table 3$)$. However, in animals fed the CASeVI diet (group V) the increased ratios of $\Sigma$ SFA to $\Sigma$ PUFA (sum of PUFAs), to $\Sigma$ UFA (sum of unsaturated fatty acids) and to $\Sigma F A$ (sum of total fatty acids) in whole blood was observed in comparison to the animals fed

Table 3. Concentration $\left(\mathrm{mg} \cdot \mathrm{g}^{-1}\right)$ of selected individual saturated fatty acids (SFAs), atherogenic-SFA (A-SFA) $)^{1}$, thrombogenic-SFA (T-SFA) ${ }^{2}$, all assayed SFAs $(\Sigma S F A)^{3}$ and all assayed fatty acids $(\Sigma F A)^{4}$, ratio of $\Sigma S F A$ to sums of polyunsaturated fatty acids ( $\left.\Sigma S F A / \Sigma P U F A\right)$, unsaturated fatty

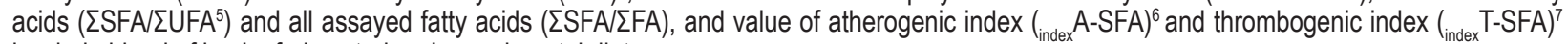
in whole blood of lambs fed control and experimental diets

\begin{tabular}{|c|c|c|c|c|c|c|c|c|c|c|c|c|}
\hline \multirow{2}{*}{ Indices } & \multicolumn{5}{|l|}{ Group $^{8}$} & \multirow{2}{*}{ SEM } & \multicolumn{6}{|c|}{ Contrast $^{9}$} \\
\hline & I (control) & II & III & IV & V & & $1 / \|$ & $\|/ /\|$ & III/IV & III/N & IVIV & I/Exp \\
\hline C10:0 & $0.94^{b c}$ & $0.82^{b}$ & $0.78^{b}$ & $1.20^{\circ}$ & $0.44^{a}$ & 0.03 & 0.19 & 0.46 & 0.03 & 0.05 & 0.01 & 0.08 \\
\hline C12:0 & $0.89^{a}$ & $1.09^{a}$ & $1.65^{b}$ & $1.48^{b}$ & $0.90^{\mathrm{a}}$ & 0.04 & 0.22 & 0.03 & 0.21 & 0.02 & 0.03 & 0.03 \\
\hline C14:0 & $4.91^{\mathrm{ab}}$ & $5.26^{b}$ & $5.30^{\mathrm{b}}$ & $4.66^{\mathrm{ab}}$ & $4.44^{\mathrm{a}}$ & 0.07 & 0.24 & 0.72 & 0.10 & 0.05 & 0.50 & 0.26 \\
\hline C15:0 & $3.28^{a b}$ & $3.59^{b}$ & $3.37^{\mathrm{ab}}$ & $3.02^{\mathrm{a}}$ & $3.09^{a}$ & 0.05 & 0.22 & 0.20 & 0.27 & 0.09 & 0.77 & 0.61 \\
\hline C16:0 & $93.1^{\mathrm{b}}$ & $87.3^{a b}$ & $90.7^{b}$ & $85.5^{\mathrm{ab}}$ & $70.7^{\mathrm{a}}$ & 3 & 0.18 & 0.27 & 0.72 & 0.02 & 0.16 & 0.40 \\
\hline C17:0 & $6.32^{b}$ & $5.64^{\mathrm{ab}}$ & $5.88^{\mathrm{ab}}$ & $5.32^{\mathrm{ab}}$ & $4.99^{a}$ & 0.4 & 0.33 & 0.42 & 0.57 & 0.06 & 0.17 & 0.03 \\
\hline C18:0 & $177^{b}$ & $148^{\mathrm{ab}}$ & $138^{a b}$ & $127^{a}$ & $126^{a}$ & 4 & 0.11 & 0.06 & 0.19 & 0.09 & 0.84 & 0.02 \\
\hline $\mathrm{C} 22: 0$ & $0.44^{\mathrm{a}}$ & $0.88^{b}$ & $0.50^{\mathrm{ab}}$ & $0.57^{\mathrm{ab}}$ & $0.45^{\mathrm{a}}$ & 0.02 & 0.02 & 0.09 & 0.53 & 0.38 & 0.26 & 0.04 \\
\hline A-SFA & $98.9^{b}$ & $93.6^{b}$ & $97.6^{b}$ & $91.6^{b}$ & $76.1^{\mathrm{a}}$ & 3 & 0.42 & 0.24 & 0.33 & 0.03 & 0.05 & 0.05 \\
\hline index $A-S F A$ & $0.33^{a}$ & $0.34^{\mathrm{a}}$ & $0.38^{\mathrm{b}}$ & $0.35^{\mathrm{ab}}$ & $0.36^{\mathrm{ab}}$ & 0.01 & 0.44 & 0.04 & 0.47 & 0.12 & 0.32 & 0.04 \\
\hline T-SFA & $275^{c}$ & $241^{b c}$ & $234^{b}$ & $218^{\mathrm{ab}}$ & $201^{a}$ & 4 & 0.09 & 0.45 & 0.36 & 0.04 & 0.27 & 0.02 \\
\hline index $\mathrm{T}-\mathrm{SFA}$ & $1.04^{b}$ & $0.97^{\mathrm{a}}$ & $1.07^{\mathrm{b}}$ & $0.97^{\mathrm{a}}$ & $1.10^{b}$ & 0.02 & 0.06 & 0.05 & 0.06 & 0.43 & 0.04 & 0.37 \\
\hline ¿SFA & $294^{b}$ & $257^{\mathrm{ab}}$ & $250^{a}$ & $232^{\mathrm{a}}$ & $214^{a}$ & 6 & 0.07 & 0.72 & 0.13 & 0.09 & 0.16 & 0.02 \\
\hline$\Sigma F A^{8}$ & $647^{\circ}$ & $585^{\mathrm{bc}}$ & $555^{b}$ & $536^{b}$ & $464^{a}$ & 11 & 0.08 & 0.34 & 0.57 & 0.03 & 0.03 & 0.02 \\
\hline 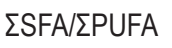 & $2.16^{b}$ & $2.10^{b}$ & $2.19^{b}$ & $1.96^{\mathrm{a}}$ & $2.30^{c}$ & 0.02 & 0.11 & 0.07 & 0.02 & 0.01 & 0.01 & 0.06 \\
\hline$\Sigma S F A / \Sigma U F A$ & $0.831^{b}$ & $0.878^{c}$ & $0.822^{b}$ & $0.765^{\mathrm{a}}$ & $0.855^{b c}$ & 0.004 & 0.03 & 0.03 & 0.02 & 0.22 & 0.01 & 0.16 \\
\hline$\Sigma$ SFA/ $\Sigma F A$ & $0.453^{b}$ & $0.440^{\mathrm{ab}}$ & $0.452^{b}$ & $0.434^{a}$ & $0.461^{b}$ & 0.003 & 0.04 & 0.05 & 0.31 & 0.03 & 0.02 & 0.27 \\
\hline
\end{tabular}

${ }^{1}$ A-SFA - sum of: C12:0, C14:0 and C16:0; ${ }^{2}$ T-SFA - sum of: C14:0, C16:0 and C18:0; ${ }^{3} \Sigma S F A-$ sum of: C6:0, C8:0, C9:0, C10:0, C11:0, C12:0,

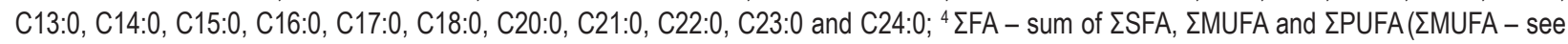
Table 4 and $\Sigma$ PUFA - see Table 5); ${ }^{5} \Sigma$ UFA - sum of $\Sigma$ MUFA and $\Sigma P U F A ;{ }^{6}$ index $A-S F A=(C 12: 0+4 \times C 14: 0+C 16: 0) /\left(\sum M U F A+\sum n-6 P U F A+\right.$

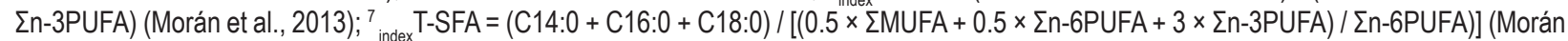
et al., 2013); ${ }^{8}$ groups according to Table 2; ${ }^{9}$ least squares means; I/II = I vs II; II/III = II vs III; III/IV = III vs IV; III/V = III vs V; IVNV = IV vs V; I/Exp = I vs all experimental groups (II-V); ab - mean values with different superscripts within the same row are significantly different at $P \leq 0.05$ 
CASeY diet (group IV) $(P \leq 0.05$; Table 3). Feeding the CASeY diet (group IV) resulted in lower $\Sigma$ SFA: $\Sigma$ PUFA, $\Sigma$ SFA: $\Sigma$ UFA and $\Sigma$ SFA: $\Sigma F A$ ratios and T-SFA, $\Sigma$ SFA and $\Sigma F A$ levels in whole blood than feeding the control diet (group I) (Table 3). In lambs fed the CASeVI diet (group V), the sum of monounsaturated fatty acids ( $\Sigma$ MUFA), but also the levels of $c$ is $9 \mathrm{C} 14: 1$ ( $c 9 \mathrm{C} 14: 1), c 9 \mathrm{C} 16: 1, c 10 \mathrm{C} 16: 1$, c9C18:1, c12C18:1 and t11C18:1 in whole blood were decreased in comparison to that of lambs fed the control diet $(P \leq 0.05$; Table 4$)$. In comparison to lambs fed ROFO, CA and CASeY diets, in lambs from CASeVI group the $\Delta 9$-desaturase index $(\Delta 9$ index) in whole blood was decreased. As a conse-

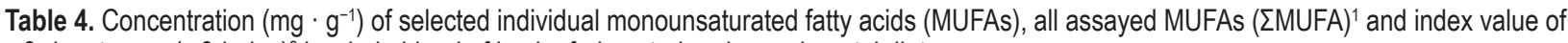
$\Delta 9$-desaturase $(\Delta 9 \text {-index })^{2}$ in whole blood of lambs fed control and experimental diets

\begin{tabular}{|c|c|c|c|c|c|c|c|c|c|c|c|c|}
\hline \multirow{2}{*}{ Indices } & \multicolumn{5}{|l|}{ Group ${ }^{3}$} & \multirow{2}{*}{ SEM } & \multicolumn{6}{|c|}{ Contrast $^{4}$} \\
\hline & I (control) & II & III & IV & V & & $\mathrm{I} / \mathrm{II}$ & $\| / I I I$ & III/IV & III/V & IV/V & I/Exp \\
\hline c9C14:1 & $2.44^{c}$ & $2.38^{c}$ & $1.40^{\mathrm{a}}$ & $1.87^{b}$ & $1.60^{\mathrm{ab}}$ & 0.07 & 0.34 & 0.02 & 0.04 & 0.19 & 0.065 & 0.02 \\
\hline c9C16:1 & $3.06^{c}$ & $3.09^{c}$ & $2.04^{a}$ & $2.67^{b c}$ & $2.43^{b}$ & 0.04 & 0.81 & 0.04 & 0.04 & 0.05 & 0.63 & 0.03 \\
\hline c10C16:1 & $2.91^{\mathrm{b}}$ & $2.85^{b}$ & $2.58^{\mathrm{ab}}$ & $2.91^{\mathrm{b}}$ & $2.38^{\mathrm{a}}$ & 0.03 & 0.39 & 0.21 & 0.19 & 0.63 & 0.02 & 0.04 \\
\hline c9C17:1 & $1.62^{b}$ & $1.41^{a}$ & $1.48^{a b}$ & $1.51^{\mathrm{ab}}$ & $1.47^{\mathrm{ab}}$ & 0.04 & 0.03 & 0.18 & 0.72 & 0.83 & 0.23 & 0.04 \\
\hline c7C18:1 & $1.34^{a}$ & $1.69^{b}$ & $1.64^{b}$ & $1.68^{b}$ & $1.69^{b}$ & 0.03 & 0.03 & 0.56 & 0.48 & 0.59 & 0.61 & 0.03 \\
\hline c9C18:1 & $178^{b}$ & $165^{b}$ & $155^{\mathrm{b}}$ & $151^{\mathrm{ab}}$ & $126^{a}$ & 5 & 0.32 & 0.27 & 0.21 & 0.02 & 0.07 & 0.03 \\
\hline c12C18:1 & $6.03^{b c}$ & $6.38^{c}$ & $5.16^{\mathrm{ab}}$ & $4.88^{a}$ & $4.44^{a}$ & 0.08 & 0.64 & 0.02 & 0.17 & 0.15 & 0.34 & 0.04 \\
\hline c11C20:1 & $1.39^{\mathrm{a}}$ & $1.57^{b}$ & $1.28^{a}$ & $1.33^{a}$ & $1.25^{\mathrm{a}}$ & 0.04 & 0.03 & 0.02 & 0.49 & 0.70 & 0.83 & 0.05 \\
\hline t11C18:1 & $7.37^{\mathrm{bc}}$ & $7.48^{c}$ & $7.83^{c}$ & $6.96^{\mathrm{ab}}$ & $5.94^{a}$ & 0.05 & 0.87 & 0.53 & 0.04 & 0.03 & 0.19 & 0.07 \\
\hline ¿MUFA & $217^{b}$ & $205^{b}$ & $190^{\mathrm{b}}$ & $185^{\mathrm{ab}}$ & $157^{a}$ & 6 & 0.28 & 0.08 & 0.11 & 0.03 & 0.13 & 0.04 \\
\hline$\Delta 9$-index & $0.50^{\mathrm{a}}$ & $0.53^{b}$ & $0.53^{b}$ & $0.54^{b}$ & $0.50^{\mathrm{a}}$ & 0.01 & 0.04 & 0.77 & 0.85 & 0.04 & 0.04 & 0.05 \\
\hline
\end{tabular}

${ }_{1}$ IMUFA - sum of: $\sum c C 14: 1, \Sigma c C 15: 1, \Sigma c C 16: 1, \Sigma t C 16: 1, \Sigma c C 17: 1, \Sigma t C 18: 1, \Sigma c C 18: 1, c 11 C 20: 1, \Sigma c C 22: 1$ and $c 15 C 24: 1 ;{ }^{2} \Delta 9$-index $=c 9 C 18: 1 /$ (c9C18:1 + C18:0); ${ }^{3}$ groups according to Table $2 ;{ }^{4}$ see Table $3 ;{ }^{\text {ab }}$ - mean values with different superscripts within the same row are significantly different at $P \leq 0.05$

Table 5. Concentration $\left(\mathrm{mg} \cdot \mathrm{g}^{-1}\right)$ of conjugated linoleic acid (c9t11CLA), selected individual polyunsaturated fatty acids (PUFAs), sums of

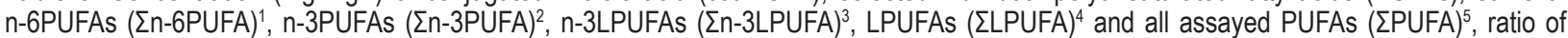

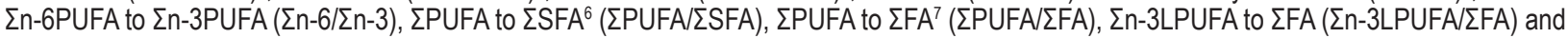
$\Sigma L P U F A$ to $\Sigma F A(\Sigma L P U F A / \Sigma F A)$, value of fatty acid elongase index $\left(\text { Elong }_{\text {index }}\right)^{8}$ and $\Delta 4$-desaturase index $(\Delta 4 \text {-index })^{9}$ in whole blood of lambs fed control and experimental diets

\begin{tabular}{|c|c|c|c|c|c|c|c|c|c|c|c|c|}
\hline \multirow{2}{*}{ Indices } & \multicolumn{5}{|l|}{ Group $^{10}$} & \multirow{2}{*}{ SEM } & \multicolumn{6}{|c|}{ Contrast ${ }^{11}$} \\
\hline & I control) I & II & III & IV & V & & $\mathrm{I} / \mathrm{I}$ & $\|/ /\|$ & III/IV & III/V & IV/N & I/Exp \\
\hline c9t11CLA & $2.36^{b}$ & $2.00^{\mathrm{ab}}$ & $1.94^{\mathrm{ab}}$ & $2.08^{b}$ & $1.67^{\mathrm{a}}$ & 0.10 & 0.09 & 0.31 & 0.53 & 0.07 & 0.02 & 0.04 \\
\hline LA & $109^{b}$ & $101^{\mathrm{ab}}$ & $94^{\mathrm{ab}}$ & $98^{\mathrm{ab}}$ & $78^{a}$ & 3 & 0.27 & 0.46 & 0.66 & 0.37 & 0.48 & 0.04 \\
\hline aLNA & $6.57^{\mathrm{b}}$ & $4.45^{\mathrm{a}}$ & $4.28^{\mathrm{a}}$ & $4.48^{\mathrm{a}}$ & $3.74^{\mathrm{a}}$ & 0.15 & 0.03 & 0.54 & 0.49 & 0.19 & 0.15 & 0.02 \\
\hline C20:4n-6 (AA) & $9.18^{c}$ & $7.81^{\mathrm{bc}}$ & $7.59^{\mathrm{ab}}$ & $6.77^{\mathrm{ab}}$ & $5.64^{a}$ & 0.21 & 0.09 & 0.72 & 0.52 & 0.40 & 0.37 & 0.03 \\
\hline C22:5n-3 (DPA) & $2.37^{\mathrm{ab}}$ & $3.04^{c}$ & $2.82^{\mathrm{bc}}$ & $2.89^{b c}$ & $2.00^{\mathrm{a}}$ & 0.04 & 0.04 & 0.37 & 0.41 & 0.04 & 0.04 & 0.08 \\
\hline C22:6n-3 (DHA) & $1.76^{\mathrm{a}}$ & $3.09^{b}$ & $1.45^{\mathrm{a}}$ & $1.73^{\mathrm{a}}$ & $1.33^{a}$ & 0.05 & 0.03 & 0.02 & 0.36 & 0.57 & 0.40 & 0.61 \\
\hline$\sum n-6 P U F A$ & $120^{b}$ & $109^{a b}$ & $102^{\mathrm{ab}}$ & $105^{\mathrm{ab}}$ & $83^{a}$ & 4 & 0.23 & 0.39 & 0.45 & 0.09 & 0.12 & 0.03 \\
\hline$\Sigma \mathrm{n}-3 \mathrm{PUFA}$ & $10.7^{b}$ & $10.6^{b}$ & $8.6^{\mathrm{ab}}$ & $9.1^{\mathrm{ab}}$ & $7.1^{\mathrm{a}}$ & 0.2 & 0.59 & 0.21 & 0.17 & 0.08 & 0.07 & 0.04 \\
\hline In-3LPUFA & $4.76^{\mathrm{ab}}$ & $6.95^{c}$ & $4.74^{\mathrm{ab}}$ & $5.26^{b}$ & $3.94^{\mathrm{a}}$ & 0.02 & 0.03 & 0.03 & 0.37 & 0.43 & 0.05 & 0.21 \\
\hline ¿LPUFA & $16.06^{c}$ & $14.77^{\mathrm{bc}}$ & $12.33^{\mathrm{ab}}$ & $12.29^{\mathrm{ab}}$ & $9.58^{\mathrm{a}}$ & 0.07 & 0.09 & 0.22 & 0.73 & 0.09 & 0.09 & 0.02 \\
\hline ¿PUFA & $136^{c}$ & $123^{\mathrm{bc}}$ & $114^{\mathrm{ab}}$ & $118^{\mathrm{bc}}$ & $93^{a}$ & 3 & 0.48 & 0.51 & 0.67 & 0.08 & 0.05 & 0.02 \\
\hline$\sum n-6 / \Sigma n-3$ & $11.43^{\mathrm{ab}}$ & $10.72^{\mathrm{a}}$ & $12.06^{b}$ & $11.63^{b}$ & $12.08^{b}$ & 0.2 & 0.25 & 0.04 & 0.31 & 0.41 & 0.09 & 0.23 \\
\hline$\Sigma \mathrm{PUFA} / \Sigma \mathrm{SFA}$ & $0.47^{a}$ & $0.48^{a b}$ & $0.46^{\mathrm{a}}$ & $0.51^{b}$ & $0.44^{a}$ & 0.01 & 0.20 & 0.17 & 0.03 & 0.77 & 0.02 & 0.27 \\
\hline$\Sigma P U F A / \Sigma F A$ & $0.211^{\mathrm{ab}}$ & $0.210^{\mathrm{ab}}$ & $0.204^{a}$ & $0.220^{\mathrm{b}}$ & $0.200^{\mathrm{a}}$ & 0.02 & 0.64 & 0.33 & 0.05 & 0.46 & 0.03 & 0.05 \\
\hline 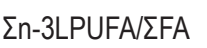 & $0.007^{a}$ & $0.012^{c}$ & $0.008^{a}$ & $0.010^{\mathrm{b}}$ & $0.008^{a}$ & 0.001 & 0.01 & 0.02 & 0.05 & 0.71 & 0.05 & 0.02 \\
\hline 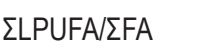 & $0.0248^{c}$ & $0.0253^{c}$ & c $\quad 0.0222^{b}$ & $0.0229^{b}$ & $0.0206^{a}$ & 0.0006 & 0.24 & 0.04 & 0.73 & 0.05 & 0.04 & 0.04 \\
\hline Elong $_{\text {index }}$ & $0.0866^{a}$ & $0.1561^{\mathrm{d}}$ & d $0.0898^{a}$ & $0.1142^{b}$ & $0.1405^{c}$ & 0.0005 & 0.01 & 0.01 & 0.04 & 0.01 & 0.09 & 0.02 \\
\hline$\Delta 4$-index & $0.432^{c}$ & $0.513^{d}$ & $0.339^{a}$ & $0.381^{\mathrm{b}}$ & $0.388^{b}$ & 0.003 & 0.04 & 0.01 & 0.05 & 0.05 & 0.39 & 0.27 \\
\hline
\end{tabular}

${ }^{1}$ Ln-6PUFA - sum of: $c 9 c 12 \mathrm{C} 18: 2$ (LA), c6c9c12C18:3 (YLNA) and En-6LPUFA (c11c14C20:2, c8c11c14C20:3, c5c8c11c14C20:4 (AA), c13c16C22:2 and c7c10c13c16C22:4); 2 nn-3PUFA-sum of: c9c12c15C18:3 (aLNA), c11c14c17C20:3, c8c11c14c17C20:4, c5c8c11c14c17C20:5

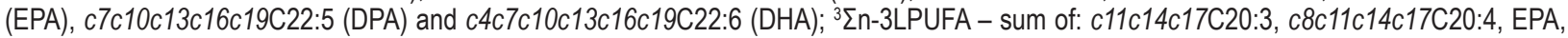

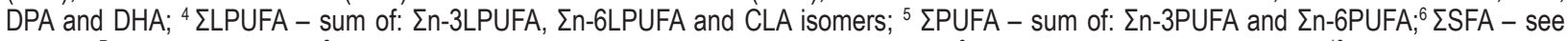
Table 3; ${ }^{7}$ LFA - see Table $3 ;{ }^{8}$ Elong $_{\text {index }}=c 11 c 14 c 17 \mathrm{C} 20: 3 /(c 11 \mathrm{c} 14 \mathrm{c} 17 \mathrm{C} 20: 3+\mathrm{aLNA}) ;{ }^{9} \Delta 4$-index = DHA / (DHA + DPA); ${ }^{10}$ groups according to Table 2; ${ }^{11}$ see Table 3 ; ab - mean values with different superscripts within the same row are significantly different at $P \leq 0.05$ 
Table 6. Concentration of total cholesterol (TCh), $\alpha$-tocopherol ( $\alpha \mathrm{T}$ ), malondialdehyde (MDA) and selected elements (Se, $\mathrm{Zn}, \mathrm{Cu}, \mathrm{Fe}, \mathrm{Mg}, \mathrm{Ca}$, $\mathrm{Pb}, \mathrm{Cd}$ and $\mathrm{As})$, and value of PUFA peroxidation index (MDA $\mathrm{index})^{1}$ in whole blood of lambs fed control and experimental diets

\begin{tabular}{|c|c|c|c|c|c|c|c|c|c|c|c|c|}
\hline \multirow{2}{*}{ Indices } & \multicolumn{5}{|c|}{ Group $^{2}$} & \multirow{2}{*}{ SEM } & \multicolumn{6}{|c|}{ Contrast $^{3}$} \\
\hline & I (control) & II & III & IV & V & & $\mid / / I$ & $\|/ /\|$ & III/IV & III/V & IV/V & I/Exp \\
\hline $\mathrm{TCh}, \mu \mathrm{g} \cdot \mathrm{g}^{-1}$ & $431^{\mathrm{ab}}$ & $412^{\mathrm{ab}}$ & $384^{a}$ & $457^{b}$ & $395^{a}$ & 3 & 0.41 & 0.08 & 0.01 & 0.53 & 0.02 & 0.05 \\
\hline aT, $\mu g \cdot g^{-1}$ & $0.60^{\mathrm{bc}}$ & $0.52^{b}$ & $0.57^{\mathrm{bc}}$ & $0.61^{\circ}$ & $0.41^{\mathrm{a}}$ & 0.02 & 0.10 & 0.22 & 0.05 & 0.04 & 0.01 & 0.02 \\
\hline $\mathrm{MDA}, \mathrm{ng} \cdot \mathrm{g}^{-1}$ & $0.35^{\mathrm{a}}$ & $0.54^{b}$ & $0.69^{c}$ & $0.94^{d}$ & $0.92^{\mathrm{d}}$ & 0.03 & 0.04 & 0.05 & 0.04 & 0.03 & 0.42 & 0.01 \\
\hline $\mathrm{MDA}_{\text {index }}$ & $2.55^{\mathrm{a}}$ & $4.37^{b}$ & $6.07^{\circ}$ & $7.93^{\mathrm{d}}$ & $9.92^{\mathrm{e}}$ & 0.02 & 0.03 & 0.05 & 0.04 & 0.02 & 0.05 & 0.01 \\
\hline Se, $\mu \mathrm{g} \cdot \mathrm{g}^{-1}$ & $0.20^{\mathrm{a}}$ & $0.20^{\mathrm{a}}$ & $0.23^{a}$ & $0.30^{c}$ & $0.26^{b}$ & 0.01 & 0.78 & 0.08 & 0.03 & 0.05 & 0.05 & 0.06 \\
\hline $\mathrm{Zn}, \mu \mathrm{g} \cdot \mathrm{g}^{-1}$ & $3.39^{\mathrm{a}}$ & $3.69^{a b}$ & $3.57^{\mathrm{a}}$ & $4.08^{c}$ & $3.89^{b}$ & 0.10 & 0.09 & 0.18 & 0.02 & 0.04 & 0.05 & 0.03 \\
\hline $\mathrm{Cu}, \mu \mathrm{g} \cdot \mathrm{g}^{-1}$ & $1.40^{\mathrm{a}}$ & $1.33^{\mathrm{a}}$ & $1.38^{\mathrm{a}}$ & $1.56^{b}$ & $1.41^{\mathrm{a}}$ & 0.02 & 0.43 & 0.71 & 0.04 & 0.67 & 0.05 & 0.19 \\
\hline $\mathrm{Fe}, \mu \mathrm{g} \cdot \mathrm{g}^{-1}$ & $441^{a}$ & $463^{a}$ & $477^{\mathrm{ab}}$ & $496^{b}$ & $457^{\mathrm{a}}$ & 6 & 0.32 & 0.46 & 0.09 & 0.14 & 0.05 & 0.27 \\
\hline $\mathrm{Mg}, \mu \mathrm{g} \cdot \mathrm{g}^{-1}$ & $83^{\mathrm{ab}}$ & $89^{b c}$ & $78^{\mathrm{a}}$ & $86^{b c}$ & $91^{c}$ & 1 & 0.11 & 0.05 & 0.04 & 0.04 & 0.09 & 0.04 \\
\hline $\mathrm{Ca}, \mu \mathrm{g} \cdot \mathrm{g}^{-1}$ & $221^{b}$ & $229^{b}$ & $199^{a}$ & $221^{b}$ & $230^{b}$ & 3 & 0.23 & 0.04 & 0.05 & 0.03 & 0.08 & 0.18 \\
\hline $\mathrm{Pb}, \mu \mathrm{g} \cdot \mathrm{g}^{-1}$ & $0.129^{b}$ & $0.132^{b}$ & $0.119^{a}$ & $0.129^{b}$ & $0.136^{b}$ & 0.003 & 0.31 & 0.04 & 0.08 & 0.04 & 0.19 & 0.24 \\
\hline $\mathrm{Cd}, \mathrm{ng} \cdot \mathrm{g}^{-1}$ & $1.52^{\mathrm{bc}}$ & $1.44^{\mathrm{bc}}$ & $1.24^{\mathrm{a}}$ & $1.59^{\circ}$ & $1.40^{b}$ & 0.04 & 0.27 & 0.04 & 0.04 & 0.14 & 0.05 & 0.11 \\
\hline As, $n g \cdot g^{-1}$ & $3.46^{c}$ & $2.93^{c}$ & $2.08^{b}$ & $1.85^{\mathrm{ab}}$ & $1.70^{\mathrm{a}}$ & 0.04 & 0.08 & 0.03 & 0.17 & 0.05 & 0.18 & 0.01 \\
\hline
\end{tabular}

${ }^{1} \mathrm{MDA}_{\text {index }}=\mathrm{MDA}\left(\mathrm{ng} \cdot \mathrm{g}^{-1}\right) /$ LPUFA $\left(\mathrm{mg} \cdot \mathrm{g}^{-1}\right)$ where PPUFA - see Table $5 ;{ }^{2}$ groups according to Table $2 ;{ }^{3}$ see Table $3 ;$ ab - mean values with different superscripts within the same row are significantly different at $P \leq 0.05$

quence, higher concentration of cis 9 trans $11 \mathrm{C} 18: 2$ (c9t11CLA; the product of $\Delta 9$-desaturation of t11C18:1) was observed in the whole blood of lambs fed the CASeY diet (group IV) than the CASeVI diet (group V) (Table 5). In lambs fed the CASeVI diet (group V), sums of n-6PUFAs ( $\Sigma$ n-6PUFA; including linoleic acid and arachidonic acid), n-3PUFAs ( $\Sigma$ n-3PUFA), LPUFAs ( $\Sigma$ LPUFA) as well as $\Sigma$ PUFA in whole blood were lower $(P \leq 0.05)$ in comparison to lambs fed the control diet (group I). The concentrations of $\Sigma$ PUFA and $c 9 t 11$ CLA were also lower in lambs fed the CASeVI diet (group V) as compared to that fed the SeY enriched diet (group IV). In lambs fed SeY supplemented diet (group IV), higher $(P \leq 0.05) \Sigma$ PUFA: $\Sigma$ SFA, $\Sigma$ PUFA: $\Sigma F A$, $\Sigma$ LPUFA: $\Sigma F A$ (inclu-ding $\Sigma$ n-3LPUFA: $\Sigma F A$ ) ratios in whole blood were found in comparison to group V. Moreover, feeding lambs with CA supplemented diets (group III, IV and V), regardless of SeY or SeVI presence, increased $(P \leq 0.05) \Sigma n-6 P U F A: \Sigma n-$ 3 PUFA ratio and values of the fatty acid elongase (Elong $\left._{\text {index }}\right)$ and the $\Delta 4$-desaturase $(\Delta 4$-index) indexes in comparison to the lambs fed ROFO diet (group II) (Table 5).

In lambs fed $\mathrm{SeY}$ enriched diet (group IV) increased concentration of total cholesterol (TCh) in whole blood was observed as compared to the CA (group III) and CASeVI (group V) diets $(P \leq 0.05$; Table 6). Also in these lambs higher $\alpha \mathrm{T}$ concentration in whole blood was noted as compared to animals fed the ROFO (group II) and CASeVI (group V) diets. On the other hand, feeding lambs $\mathrm{CASeVI}$ diet (group V) resulted in the lowest $\alpha \mathrm{T}$ level in whole blood in comparison to other groups. In animals fed diets containing $\mathrm{SeY}$ or SeVI (group IV and V) the highest $(P \leq 0.05)$ concentration of MDA and values of the PUFAs peroxidation index $\left(\mathrm{MDA}_{\text {index }}\right)$ in whole blood were found in comparison to lambs fed control and other experimental diets. Moreover, the addition of FO to the diet, irrespective of the presence of $\mathrm{CA}, \mathrm{SeY}$ or SeVI, increased the $\mathrm{MDA}_{\text {index }}$ and accumulation of MDA in whole blood in comparison to the control diet $(P \leq 0.05)$.

In lambs fed $\mathrm{SeY}$ or $\mathrm{SeVI}$ supplemented diets (group IV and V), the concentration of Se in whole blood was higher in comparison to the values for lambs fed control (group I), ROFO (group II) and CA (group III) diets $(P \leq 0.05$; Table 6). Moreover, the Se whole blood content was higher $(P \leq 0.05)$ in lambs fed diet enriched with SeY (group IV) than in lambs fed diet with SeVI (group V). No statistical differences in Se concentration were observed among lambs fed control, ROFO or CA diets (groups I-III).

Feeding lambs diet with $\mathrm{SeY}$ addition (group IV) increased $\mathrm{Zn}$ and $\mathrm{Cu}$ whole blood content as compared to all other animals. Moreover, feeding lambs diet containing SeY increased the concentrations of $\mathrm{Fe}$ in whole blood as compared to all other groups except animals fed CA diet (group III; $P \leq 0.05$ ). At the same time, feeding lambs with CA diet (group III) resulted in lower concentrations of $\mathrm{Mg}, \mathrm{Ca}$ and $\mathrm{Pb}$ in whole blood in comparison to the other experimental diets (group II, IV, V). The concentrations of $\mathrm{Cd}$ was the lowest in lambs fed 
CA diet (group III) and the whole blood content of As was lower when lambs were fed diets containing CA regardless Se supplementation (groups III-V) in comparison to lambs fed control (group I) and ROFO (group II) diets.

\section{Discussion}

The applied dietary manipulations did not negatively influence the welfare and general health status of the lambs, since neither macroscopic lesions nor pathological changes were found in whole blood samples as well as in all internal organs, muscles and adipose tissues of lambs fed experimental diets, irrespective of the presence of $\mathrm{SeY}$ or $\mathrm{SeVI}$ as already shown in previous experiments using the same feed supplements (Rozbicka-Wieczorek et al., 2016a,b,c). In fact, diets containing up to $2 \mathrm{ppm}$ Se are not toxic for ruminants (McDowell et al., 2005; Eun et al., 2013). In contrast, chronic dietary supplementation with inorganic Se-compounds, particularly selenite or selenides, at rates of more than $5 \mathrm{ppm}$ can be toxic and have a teratogenic effect in ruminants (McDowell et al., 2005; Navarro-Alarcon and Cabrera-Vique, 2008).

In our experiment it was shown that feeding the CASeVI diet improved growth parameters (BW and FCE) as compared with the control, CA and CASeY diets (Table 2). Indeed, our recent studies indicated that the CASeVI diet most effectively stimulated the bacterial protein synthesis in the lamb rumen, while it decreased the ruminal formation of volatile fatty acids (VFA) as well as $\mathrm{CH}_{4}$ and $\mathrm{CO}_{2}$ emissions as compared to control and $\mathrm{CASeY}$ diets (RozbickaWieczorek et al., 2016c). Elimination of waste products as $\mathrm{CO}_{2}$ and especially $\mathrm{CH}_{4}$ (the high-energy compound), causes the loss of $\sim 8 \%$ of the total digestible energy of the diet (Wolin, 1979). On the other hand, the CASeY diet most efficiently stimulated methanogenesis i.e. ruminal formation of $\mathrm{CH}_{4}$ as well as $\mathrm{CO}_{2}$ (Rozbicka-Wieczorek et al., 2016c). Thus, the CASeY diet resulted in the decrease in growth parameters of lambs in comparison to control, CA and especially CASeVI diets (Table 2).

Our study revealed that diet enriched with SeVI reduced the concentration of $\Sigma F A$ and $\Sigma$ PUFA in blood. These findings are in agreement with the previous studies where the addition of SeVI or selenite to the diet reduced the sum of total fatty acids in lamb muscles (Navarro-Alarcon and Cabrera-Vique, 2008; Miltko et al., 2016; RozbickaWieczorek et al., 2016a). Therefore, the results of the present study support the hypothesis that pro- oxidative effects of inorganic forms of Se-compounds (like selenite and SeVI) resulted from the catalysis of hydrosulphide oxidation that decreases the synthesis yield of lipogenic enzymes (like fatty acid synthase and acetyl-CoA carboxylase) in mammal tissues. Our previous study (RozbickaWieczorek et al., 2016c) also demonstrated that SeVI addition to diet containing 2\% RO, $1 \% \mathrm{FO}$ and CA decreased the capacity of carbohydrate fermentation into VFA and lipogenic enzymes in the lamb body, whereas stimulated the microorganism protein biosynthesis in the rumen. Moreover, the present data are in agreement with the results of Czauderna et al. (2012), in which diet containing only SeVI reduced the concentration of $\Sigma F$, especially $\Sigma$ PUFA and $\mathrm{M}$ MFA, in longissimus dorsi (LD) and biceps fermoris (BF) muscles of lambs in comparison to animals fed control diet or diet supplemented with linseed oil. Our recent investigations (Miltko et al., 2016) indicated that the lowest concentration of acetic acid in the ruminal fluid collected from lambs fed experimental diet with SeVI was associated with decreased biosynthesis yield of acetyl-CoA to lipids in lamb tissues. It is well-known that acetic acid is the main source of acetyl-CoA for the biosynthesis of lipids in mammal tissues and is oxidized to generate adenosine triphosphate (Wolin, 1979; Yang, 2014). On the other hand, the same experiment (Miltko et al., 2016) revealed that the CASeY diet (rich in Se-Met) most effectively increased microbial production of acetic acid in the rumen. The highest concentration of acetic acid in the rumen of lambs fed the CASeY diet resulted in an increase of acetyl-CoA to lipids biosynthesis yield in lamb tissues (Wolin, 1979; Miltko et al., 2016). Therefore, it can be concluded that this is the reason why the CASeY diet more effectively increased the concentration of $\Sigma F A$, especially $\Sigma$ PUFA in whole blood, as shown in the present study or in LD and BF muscles of lambs (Rozbicka-Wieczorek et al., 2016a) when compared to the CASeVI diet. Similarly to Se-supplemented diets, the experimental diet with only CA addition reduced the bioaccumulation of $\Sigma F A$, including $\Sigma$ SFA and especially $\Sigma$ LPUFA, in whole blood in comparison to the control diet. This CA supplemented diet more effectively reduced the concentration of VFAs (especially acetic acid) in the rumen as compared to the control diet as well as $\Delta 4$-index (Table 5) in comparison to the control and other experimental diets (Rozbicka-Wieczorek et al., 2016c).

Our results have demonstrated that all experimental diets reduced the concentration of $\alpha \mathrm{LNA}$ 
in comparison to the control diet (Table 5). On the other hand, the ROFO diet most effectively increased the concentration of DPA, DHA, $\Sigma \mathrm{n}-3$ LPUFA as well as Elong index $_{\text {and }} \Delta 4$-index in whole blood. So, it could be suggested that FO added to the diet with RO stimulated the anabolism (elongation and desaturation) of $\alpha \mathrm{LNA}$ in blood. In contrast, the experimental diet containing SeVI reduced the concentration of $\Sigma$ LPUFA, AA and $\Sigma$ LPUFA: $2 F A$ ratio in comparison to the control and the ROFO diets. It can be suggested that SeVI added to the experimental diet stimulated the metabolic transformations of $\alpha$ LNA and LA as well as $\Sigma$ LPUFA (including $\Sigma$ n-3LPUFA) in whole blood in comparison to the control and ROFO diet.

It was observed that the experimental diet with SeY more effectively stimulated $(P \leq 0.05)$ the accumulation of TCh as well as Se in whole blood than CA and CASeVI diets (Table 6). Moreover, the $\mathrm{CASeY}$ diet increased the concentrations of TCh and Se in blood of lambs in comparison to the control and ROFO diets, but these differences were not always statistically significant. Thus, our results are consistent with the findings reported by the research team from the University's Warwick Medical School (2009). In this study, Se-supplemented rats had higher total and non-HDL cholesterol levels in blood and triacylglycerols concentrations in liver, which may provide a possible explanation for the lipogenic effects of diets containing extra Se. Also Stranges et al. (2010) have found that the high levels of Se in diet are associated with increased TCh in human blooda parameter that is related with heart disease.

In fact, Se-Cys-containing enzymes and cholesterol biosynthesis are linked through the common use of isopentenyl pyrophosphate both for the biosynthesis of unique tRNA (referred to as tRNA ${ }^{[\mathrm{Ser}] \mathrm{Sec}}$ ) (Jameson and Diamond, 2004) and for isoprenoid biosynthesis in the mevalonate pathway (Stranges et al., 2010).

As expected, it was found that the concentration of Se in whole blood of lambs fed the CASeY diet was higher than in blood of lambs fed the CASeVI diet. The concentration of Se in whole blood is proportional to $\mathrm{Se}$ intake, although it is also affected by the chemical form of Se (Navarro-Alarcon and Cabrera-Vique, 2008). Se derived from dietary SeY (rich in Se-Met) is more efficiently accumulated in the animal tissues than inorganic chemical forms of Se (like SeVI or selenite) introduced via inorganic supplementation (Juniper et al., 2008). Dietary Se-Met is mainly incorporated into body proteins instead of methionine (Raymond et al., 2014).
These Se-Met containing proteins are not considered as Se-proteins (Raymond et al., 2014). Another study also indicates that Se-Met derived from dietary SeY is retained in tissue proteins to a greater extent than dietary $\mathrm{Se}$ as $\mathrm{SeVI}$ or selenite (Navarro-Alarcon and Cabrera-Vique, 2008). In fact, these inorganic Secompounds are metabolized to the common intermediate selenide, which may be used for the biosynthesis of the specific Se-cysteine containing proteins (e.g., glutathione peroxidases, thioredoxin reductases, selenoprotein $\mathrm{P}$, selenoprotein $\mathrm{W}$, iodothyronine deiodinases or selenophosphate synthetase) or can be excreted via two metabolic pathways (Juniper et al., 2008).

Se intake may be related to differences in concentrations of $\alpha \mathrm{T}$ in animal tissues and in values of $\mathrm{MDA}_{\text {index }}$ - the non-invasive biomarker index of lipid peroxidation induced by oxidative stress (Table 6). Our results suggested that the experimental diet supplemented with SeVIincreased oxidative stress in whole blood in comparison to the experimental diet enriched with SeY (rich in Se-Met). Recent studies revealed that $\mathrm{SeVI}$ at increased dietary concentrations may act as a pro-oxidant, while Se-Met did no exert such effect (Navarro-Alarcon and Cabrera-Vique, 2008). Interestingly, our study documented that the CASeVI diet increased the concentration of MDA and the values of $\mathrm{MDA}_{\text {index }}$ in comparison to control, ROFO and CA diets. So, the addition of SeVI to diet enriched with $\mathrm{FO}$ and CA appeared to most efficiently stimulate the oxidative stress in whole blood in comparison to the other additives supplemented to lamb diets. As a consequence, the experimental diet with SeVI (group V) most efficiently reduced the concentration of $\alpha \mathrm{T}$ in whole blood.

Also, CA diet stimulated the peroxidation of PUFAs in whole blood, as the concentration of MDA and the value of $\mathrm{MDA}_{\text {index }}$ were increased in comparison to the control and ROFO diets. Thus, our study supports the finding that dietary CA stimulated the biosynthesis of aldehydes (i.e. volatile species from lipid autoxidation) in selected tissues of lambs (Morán et al., 2013; Rozbicka-Wieczorek et al., 2016c). On the other hand, lower levels of CA $\left(\leq 0.6 \mathrm{~g} \cdot \mathrm{kg}^{-1}\right)$ stimulated an antioxidant effect in tissues closer to that observed in lambs fed diets supplemented with vitamine E (Morán et al., 2013).

Considerable attention has recently been focused on interactions between Se and other essential and toxic elements in tissues of farm animals. Animal blood analyses are routinely used for the overall assessment of health status because they are significantly correlated with the nutritional status of selected trace and toxic elements; moreover, unlike muscles 
or internal organs, blood is easier to collect (Kincaid, 1999).

Our results documented that the diet supplemented with SeY (rich in Se-Met) increased content of $\mathrm{Zn}, \mathrm{Cu}$ and $\mathrm{Fe}$ in whole blood in comparison to control and other experimental diets (Table 6). Se is an important component of several biologically significant macromolecules (like proteins containing Se-CyS or Se-Met) that interact in mammal tissues with a wide range of heavy metals and metalloids such as $\mathrm{Cu}, \mathrm{Zn}, \mathrm{Hg}, \mathrm{Ag}, \mathrm{Cd}, \mathrm{Mn}, \mathrm{Ni}, \mathrm{Cr}$ or Sb (Gailer, 2002). Various mechanisms were proposed to explain the interactions between Se and these trace elements in mammal tissues. Firstly, reactions between metal and selenide ([-Se- $\left.]^{2-}\right)$ lead to the in vivo formation of insoluble or stable selenides with metal ions. Secondly, Se is able to bind to a sulphydryl group of pre-existing proteins, and then the Se-group of biomolecules subsequently binds heavy metal ions (Gailer, 2002). The chemistry of Se documents that is almost $100 \%$ present as selenol in mammals' tissues. At physiological $\mathrm{pH}$, selenohydryl groups ( $\mathrm{RSeH}$ ) exist almost completely in an anionic form: [RSe-] (unlike the sulpfhydryl group which exists almost in the protonated form: RSH). The anionic form of the selenohydryl group is a nucleophile that binds ions of metalloids and heavy metals (Gailer, 2002). So, it can be concluded that dietary SeY (group IV) more effectively stimulated the biosynthesis of metal binding Se-biomolecules in whole blood than SeVI (group V).

$\mathrm{Pb}, \mathrm{Cd}, \mathrm{Hg}$ and As (environmental pollutants) have no biochemical functions in mammals and are toxic even at minimum concentrations; deposition of these elements in the internal organs of sheep followed the order: liver $>$ kidneys $>$ lungs $>$ small intestine $>$ heart $>$ brain. Because red blood cells in ruminants have a life span of about 130-150 days (Adili and Melizi, 2014), levels of these elements in whole blood often change with a slow rate. Consequently, the experimental diets enriched with SeY or SeVI revealed negligible influence on the concentrations of macro bioelements ( $\mathrm{Ca}$ and $\mathrm{Mg}$ ) and trace toxic metals (i.e. $\mathrm{Pb}$ and $\mathrm{Cd}$ ) in whole blood as compared to the control and ROFO diets. On the other hand, $\mathrm{CA}$ added to the diet containing $\mathrm{RO}$ and FO (group III) resulted in an antagonistic effect on the accumulation yield of $\mathrm{Pb}$ and $\mathrm{Cd}$ in the liver, $\mathrm{LD}$ and BF muscles (Ruszczyńska et al., 2016) but also in whole blood in comparison to control and other experimental diets (Table 6). Similarly, the lower concentration of As (the metalloid) was observed in whole blood of lambs fed experimental diets with
CA, irrespective of the presence of SeY and SeVI, as compared to control and ROFO diets. Antagonistic interactions are observed between Se-compounds and As-species in mammal tissues (Gailer, 2002).

\section{Conclusions}

Dietary fish oil (FO), rich in long-chain n-3 polyunsaturated fatty acids (n-3LPUFAs), increased concentrations of LPUFAs as well as products of PUFA peroxidation in whole blood of lambs but did not influence concentration of essential elements. Addition of antioxidants such as carnosic acid (CA), selenized-yeast $(\mathrm{SeY})$ or selenite $(\mathrm{SeVI})$ into diets with FO and rapeseed oil affected the fatty acids profile, total cholesterol and tocopherols content in blood but surprisingly did not reduce the concentrations of malondialdehyde. Also selected elements were modified by anti-oxidants addition.

We argue that our presented results constitute valuable information for nutritionists who conduct studies on the nutritional quality of ruminant diets enriched in FO as well as antioxidants $\mathrm{CA}, \mathrm{SeY}$ and $\mathrm{SeVI}$. Anyway, further research is necessary to fully elucidate the fact that addition of FO without/with these antioxidants to the diet induces changes in the concentration of amino acids (especially essential amino acids), vitamins A, B, D or C and other macro and trace elements in whole blood and other ruminant tissues.

\section{Acknowledgements}

This study was partially supported by the National Science Centre: Grant No. 2013/09/B/ NZ9/00291 and by the statutory funds from the Kielanowski Institute of Animal Physiology and Nutrition, Polish Academy of Sciences (Jabłonna, Poland). E. Bulska and A. Ruszczyńska acknowledge the financial support by Project No. 2012/05/B/ST4/01219 financed by the National Science Centre.

\section{References}

Adili N., Melizi M., 2014. Preliminary study of the influence of red blood cells morphometry on the species determinism of domestic animals. Vet. World 7, 219-223, https://doi.org/10.14202/vetworld.2014.219-223

AOAC International, 2005. Official Methods of Analysis of AOAC International. 18 th Edition. Gaithersburg, MD (USA)

Birtić S., Dussort P., Pierre F.-X., Bily A.C., Roller M., 2015. Carnosic acid. Phytochemistry 115, 9-19, https://doi.org/10.1016/j.phytochem.2014.12.026 
Czauderna M., Kowalczyk J., Krajewska K.A., Leng L'., 2010. Selenite, selenized yeast, or conjugated linoleic acid isomers supplemented to the diet influence the fatty acid profile in the spleen and blood plasma of rats. J. Anim. Feed Sci. 19, 613-627, https://doi.org/10.22358/jafs/66335/2010

Czauderna M., Kowalczyk J., Marounek M., 2011. The simple and sensitive measurement of malondialdehyde in selected specimens of biological origin and some feed by reversed phase high performance liquid chromatography. J. Chromatogr. B 879, 2251-2258, https://doi.org/10.1016/j. jchromb.2011.06.008

Czauderna M., Kowalczyk J., Marounek M., 2012. Dietary linseed oil and selenate affect the concentration of fatty acids in selected tissues of sheep. Czech J. Anim. Sci. 57, 389-401

Czauderna M., Kowalczyk J., Niedźwiedzka K.M., 2009b. Simple HPLC analysis of tocopherols and cholesterol from specimens of animal origin. Chem. Anal. Warsaw 54, 203-214

Czauderna M., Kowalczyk J., Niedźwiedzka K.M., Leng L., Cobanova K., 2009a. Dietary selenized yeast and CLA isomer mixture affect fatty- and amino acid concentrations in the femoral muscles and liver of rats. J. Anim. Feed Sci. 18, 348-361, https://doi.org/10.22358/jafs/66399/2009

Eun J.S., Davis T.Z., Vera J.M., Miller D.N., Panter K.E., ZoBell D.R., 2013. Addition of high concentration of inorganic selenium in orchardgrass (Dactylis glomerata L.) hay diet does not interfere with microbial fermentation in mixed ruminal microorganisms in continuous cultures. Prof. Anim. Sci. 29, 39-45, https://doi.org/10.15232/S1080-7446(15)30193-5

Gailer J., 2002. Review: Reactive selenium metabolites as targets of toxic metals/metalloids in mammals: a molecular toxicological perspective. Appl. Organometal. Chem. 16, 701-707, https://doi.org/10.1002/aoc.376

Jameson R.R., Diamond A.M., 2004. A regulatory role for Sec tRNA ${ }^{[S e r] S e c}$ in selenoprotein synthesis. RNA 10, 1142-1152, https://doi.org/10.1261/rna.7370104

Jones M.L., Allison R.W., 2007. Evaluation of the ruminant complete blood cell count. Vet. Clin. North Am. Food Anim. Pract. 23, 377-402, https://doi.org/10.1016/j.cvfa.2007.07.002

Juniper D.T., Phipps R.H., Ramos-Morales E., Bertin G., 2008. Effect of dietary supplementation with selenium-enriched yeast or sodium selenite on selenium tissue distribution and meat quality in beef cattle. J. Anim. Sci. 86, 3100-3109, https:// doi.org/10.2527/jas.2007-0595

Kincaid R.L., 1999. Assessment of trace mineral status of ruminants: A review. Proc. Am. Soc. Anim. Sci. 1999, 1-10

Kurek E., Ruszczyńska A., Wojciechowski M., Czauderna M., Bulska E., 2009. Study on speciation of selenium in animal tissues using high performance liquid chromatography with on-line detection by inductively coupled plasma mass spectrometry. Chem. Anal. Warsaw 54, 43-57

McDowell L.R., Davis P.A., Cristaldi L.A., Wilkinson N.S., Buergelt C.D., Van Alstyne R., 2005. Toxicity of selenium: Fear or precaution? Feedstuffs 77 (22), 12-13

Miltko R., Rozbicka-Wieczorek J.A., Więsyk E., Czauderna M., 2016. The influence of different chemical forms of selenium added to the diet including carnosic acid, fish oil and rapeseed oil on the formation of volatile fatty acids and methane in rumen and fatty acid profiles in the rumen content and muscles of lambs. Acta Vet. Beograd 66, 373-391, https://doi. org/10.1515/acve-2016-0032

Morán L., Giráldez F.J., Panseri S., Aldai N., Jordán M.J., Chiesa L.M., Andrés S., 2013. Effect of dietary carnosic acid on the fatty acid profile and flavour stability of meat from fattening lambs. Food Chem. 138, 2407-2414, https://doi.org/10.1016/j. foodchem.2012.12.033
Navarro-Alarcon M., Cabrera-Vique C., 2008. Selenium in food and the human body: A review. Sci. Total Environ. 400, 115-141, https://doi.org/10.1016/j.scitotenv.2008.06.024

Niedźwiedzka M.K., Kowalczyk J., Czauderna M., 2008. Influence of selenate and linseed oil on fatty-acid and amino-acid profiles in the liver, muscles, fat tissues and blood plasma of sheep. J. Anim. Feed Sci. 17, 328-343, https://doi.org/10.22358/ jafs/66612/2008

Orth M., Bellosta S., 2012. Cholesterol: its regulation and role in central nervous system disorders. Cholesterol 2012, 292598, https://doi.org/10.1155/2012/292598

Raymond L.J., Deth R.C., Ralston N.V.C., 2014. Potential role of selenoenzymes and antioxidant metabolism in relation to autism etiology and pathology. Autism Res. Treat. 2014, 164938, https://doi.org/10.1155/2014/164938

Risé P., Eligini S., Ghezzi S., Colli S., Galli C., 2007. Fatty acid composition of plasma, blood cells and whole blood: Relevance for the assessment of the fatty acid status in humans. Prostaglandins Leukot. Essent. Fatty Acids 76, 363-369, https:// doi.org/10.1016/j.plefa.2007.05.003

Rozbicka-Wieczorek A.J., Czauderna M., Więsyk E., Radzik-Rant A., 2016a. Selenium species in diet containing carnosic acid, fish and rapeseed oils affect fatty acid profiles in lamb muscles. J. Anim. Feed Sci. 25, 216-225, https://doi.org/10.22358/ jafs/65555/2016

Rozbicka-Wieczorek A.J., Krajewska-Bienias K.A., Czauderna M., 2016b. Dietary carnosic acid, selenized yeast, selenate and fish oil affected the concentration of fatty acids, tocopherols, cholesterol and aldehydes in the brains of lambs. Arch. Anim. Breed. 59, 215-226, https://doi.org/10.5194/aab-59-215-2016

Rozbicka-Wieczorek A.J., Więsyk E., Brzóska F., Śliwiński B., Kowalczyk J., Czauderna M., 2014. Efficiency of fatty acid accumulation into breast muscles of chickens fed diets with lycopene, fish oil and different chemical selenium forms. Afr. J. Biotechnol. 13, 1604-1613, https://doi.org/10.5897/ AJB2013.13275

Rozbicka-Wieczorek A.J., Więsyk E., Krajewska-Bienias K.A., Wereszka K., Czauderna M., 2016c. Supplementation effects of seleno-compounds, carnosic acid, and fish oil on concentrations of fatty acids, tocopherols, cholesterol, and amino acids in the livers of lambs. Turk. J. Vet. Anim. Sci. 40, 681-693, https://doi.org/10.3906/vet-1509-12

Ruszczyńska A., Rutkowska D., Bulska E., Czauderna M., 2016. Effects of carnosic acid, fish oil and seleno-compounds on the level of selenium and fatty acids in lamb muscles. In: Proceedings of XLV Scientific Session of Group of Animal Nutrition KNZiA-PAN Olsztyn (Poland), pp. 90-91

Skeaff C.M., Hodson L., McKenzie J.E., 2006. Dietary-induced changes in fatty acid composition of human plasma, platelet, and erythrocyte lipids follow a similar time course. J. Nutr. 136, 565-569

Stranges S., Laclaustra M., Ji C., Cappuccio F.P., Navas-Acien A., Ordovas J.M., Rayman M., Guallar E., 2010. Higher selenium status is associated with adverse blood lipid profile in British adults. J. Nutr. 140, 81-87, https://doi.org/10.3945/ jn.109.111252

Strzetelski J.A., Brzóska F., Kowalski Z.M., Osięgłowski S., 2014. Feeding Recommendation for Ruminants and Feed Tables (in Polish). National Research Institute of Animal Production, Kraków (Poland), pp. 392

University of Warwick, 2009. Too much selenium can increase your cholesterol. Science Daily, 13 November 2009, www.sciencedaily.com/releases/2009/11/091112103417.htm 
Wąsowska I., Maia M.R.G., Niedźwiedzka K.M., Czauderna M., Ramalho Ribeiro J.M.C., Devillard E., Shingfield K.J., Wallace R.J., 2006. Influence of fish oil on ruminal biohydrogenation of $\mathrm{C} 18$ unsaturated fatty acids. Br. J. Nutr. 95, 1199-1211, https://doi.org/10.1079/BJN20061783

Wolin M.J., 1979. The rumen fermentation: a model for microbial interactions in anaerobic ecosystems. In: M. Alexander (Editor). Advances in Microbial Ecology. Volume 3. Plenum Press. New York, NY (USA), pp. 49-77, https://doi. org/10.1007/978-1-4615-8279-3_2
Yang C.-M.J., 2014. Response of forage fiber degradation by ruminal microorganisms to branched-chain volatile fatty acids, amino acids, and dipeptides. J. Dairy Sci. 85, 1183-1190, https://doi. org/10.3168/jds.S0022-0302(02)74181-7 